\title{
Monocyte Differentiation Antigen CD14
}

National Cancer Institute

\section{Source}

National Cancer Institute. Monocyte Differentiation Antigen CD14. NCI Thesaurus. Code C17488.

Monocyte differentiation antigen CD14 (375 aa, $40 \mathrm{kDa}$ ) is encoded by the human CD14 gene. This protein plays a role in the innate immune response to lipopolysaccharide exposure. 